\author{
Proceedings of the Annual Conference of the Agricultural Extension Society of \\ Nigeria \\ Number: Twenty-Second Annual Conference \\ Theme: Mainstreaming Entrepreneurship in Agricultural Extension Practice in Nigeria \\ Date: $23^{\text {rd }}-26^{\text {th }}$ April, 2017. Venue: University of Port Harcourt, River State, Nigeria \\ ISSN: 1595 - 1421.http://aesonnigeria.org/ConfProc . Email: editorinchief@aesonnigeria.org
}

\title{
Effect of Soybean Utilisation on Child Nutrition in Chikun LGA of Kaduna State https://dx.doi.org/10.4314/jae.v22i1.22S
}

\section{Kormawa A. J, Aminu O. O. and Akinbile L. A}

Department of Agricultural Extension and Rural Development, University of Ibadan, Nigeria lakinbile@yahoo.com/08023250454, funmiaminu@yahoo.com/08060990906

\begin{abstract}
The study assessed soybean utilisation and child nutrition among households in Chikun LGA of Kaduna State. This was done by examining trained and untrained households with respect to nutritional status of children below the age of five. Data was obtained through questionnaires. This was supported by anthropometric measurement of children's weight and height. Most (58.4\%) household heads were between the ages of 36-40 years and majority (78.3\%) of the household members had formal education. Primary occupation engaged in by households were farming (35.3\%) and trading (25.0\%). Plant protein constitutes the main source of protein and the most preferred by respondents. Only one soybean product - dadawa was being used by untrained households. However, trained households were using soybean to make dadawa, moinmoin, soymilk, soy ogi and soup. Majority (62.3\%) of the children below the age of five years were normal. Children from trained households suffer less malnutrition than those from untrained households. Also, $18.1 \%$ of children from trained households were better off in terms of normal growth than $10.7 \%$ of those from untrained households. Lack of processing equipment and time factor were major constraints to soybean utilisation. A significant difference in soybean utilisation existed between trained and untrained households $(t=12.4 . p \leq 0.01)$. There was a significant relationship between nutritional status of children and soybean utilisation $(r=0.34 . p \leq 0.01)$. Also, there was a significant difference in nutritional status of children from trained and untrained households ( $t=2.32$. $p \leq 0.01)$. The study concluded that effective training on soybean utilisation innovations is key to improved protein malnutrition and child health in the study area.
\end{abstract}

Keywords: Soybean utilization, rural households, child nutrition

\section{Introduction}

Soybean scientifically referred to as (Glycine MaxL) is an annual herbaceous plant which is bushy, erect and with leafy plant structure. It is a farm crop that belongs to the family of legumes. Leguminous plants are excellent source of protein that helps in building human body cells. According to Amusat and Ademola (2013), legumes such as soybean is a cheap source of quality protein that is superior to all other plant foods because it has good balance of the essential amino acids. Soybeans are regarded as equal in protein quality to animal foods (World's Healthiest Food, 2011). However, in terms of consumption cowpea is widely consumed in Nigeria perhaps due to ease of availability and preparation. Majority of the population depend on plant protein sources for their protein intake. This is particularly due to high cost of 


\section{Proceedings of the Annual Conference of the Agricultural Extension Society of Nigeria \\ Number: Twenty-Second Annual Conference \\ Theme: Mainstreaming Entrepreneurship in Agricultural Extension Practice in Nigeria \\ Date: $23^{\text {rd }}-26^{\text {th }}$ April, 2017. Venue: University of Port Harcourt, River State, Nigeria \\ ISSN: 1595 - 1421.http://aesonnigeria.org/ConfProc . Email: editorinchief@aesonnigeria.org}

animal protein sources such as meat, fish and eggs coupled with cultural factors

which sometimes forbids their use by certain physiological groups.

In the same vein, Horizon International (2011) noted that soybean-fortified products not only have more protein and minerals than their non-fortified counterparts, they are considerably cheaper than other sources of high-quality protein such as fish, meat, milk and other protein-rich legumes. It was stated in a report that soybeans are about $40 \%$ protein - more protein-rich than any of the common vegetable or animal food sources found in Africa (Horizon International, 2011). It was estimated that the cost of protein, when purchased as soybean, is only about $10-20 \%$ of the cost of protein from fish, meat, eggs or milk. Soybean is a rich source of edible vegetable oil, vitamin and minerals. It contains about $20 \%$ oil, which is $85 \%$ unsaturated and cholesterol free. Corroborating this, Olatunji, Etuk and Adesope (2012) reported that soybean oil is rich in fatty acids and devoid of cholesterol and that it is an excellent source of calcium, iron and vitamins such as thiamin, riboflavin and niacin.

According to the National Soybean Research Laboratory of Illinois in America, the high protein soybean milk and lactose free is a suitable low cost way of providing better nutrition and improved health (Niyibituronsa, Kyallo, Mugo and Gaidashova, 2014). Soybean can be processed into dadawa, soymilk, soy oil, soy ogi, soy akara, soy flour, soygari and soy cheese like soybean curd rich in protein. These various soybean products can be produced for home consumption and sales to enhance the entrepreneurship development of rural households. Interestingly, the medicinal nature of soybean is extremely essential in building body immune system (Amusat and Ademola, 2013). Additionally, Soy food has been reported to provide significant health benefits but not total protection against heart diseases, high blood pressure, stroke, ulcer, menopause, diabetes and cancer (World's Healthiest Foods, 2004; Fabiyi, 2006; Olatunji, Etuk and Adesope 2012).

Soybean utilisation is very essential for the enhancement of child nutrition. Soybean intake during childhood is associated with lower incidence of breast cancer. Soy products provide essential nutrients such as calcium, zinc, iron and folate for growth and development. It can provide added fibre to kids' diets, which generally need a boost. Combining soy protein with cereal grains increase protein quantity and quality in cereal products. Soy is a cost-effective ingredient, making it ideal for foodservice and for products that fit into the family budget. Parents respond favourably to seeing soy on the ingredient label and consider foods containing soy to be healthy. Low-calorie, nutrient-dense soy foods can help reduce malnutrition and combat the obesity epidemic.

The frequency of serving soybean products is mostly decided by mothers and previous study suggested that mother's food habits affect their children's preferences (Osera, Tsutie, Kobayashi, Kurihara 2012; Osera, Tsutie, Kobayashi, Segawa, Kurihara 2016). Hence, the intake of soybean products from childhood may lead to positive effects in Childs' health. Malnutrition in children is synonymous to undernutrition which is common globally and results in both short and long term irreversible negative health outcomes including stunted growth which may also be linked to cognitive development deficits, underweight and wasting (Wikipedia the free encyclopaedia, 2017). Stunting, wasting, and underweight are among those Anthropometric indicators commonly used to measure malnutrition in a population of 


\section{Proceedings of the Annual Conference of the Agricultural Extension Society of Nigeria \\ Number: Twenty-Second Annual Conference \\ Theme: Mainstreaming Entrepreneurship in Agricultural Extension Practice in Nigeria \\ Date: $23^{\text {rd }}-26^{\text {th }}$ April, 2017. Venue: University of Port Harcourt, River State, Nigeria \\ ISSN: 1595 - 1421.http://aesonnigeria.org/ConfProc . Email: editorinchief@aesonnigeria.org}

under five children. Underweight (low weight-for-age) reflects both low height-for-age and low weight-for-age and therefore reflects both cumulative and acute exposures of malnutrition (Janevic, Petrovic, Bjelic and Kubera, 2010 cited in Bantamen, Belaynew and Dube, 2014).

According to World Health Organisation report, malnutrition accounts for 54 percent of child mortality worldwide and childhood underweight is the cause for about $35 \%$ of all deaths of children under the age of five years worldwide (Walker, 2008 and Prüss-Üstün, 2008). You, Jones and Wardlaw (2012) cited in John, Zacharia and James (2015) reported that in 2011, the United Nations estimated 6.9 million deaths of under-five children and mortality rates are concentrated in SubSaharan Africa. It has been discovered that the nutrition of children 5 years and younger depends strongly on the nutrition level of their mothers during pregnancy and breastfeeding (Wikipedia the free encyclopedia, 2017). Hinged on the fact that consumption of soybean by mothers and children can help boost nutritional status, the study examined the utilisation of soybean and child nutritional status among producing and non-producing households in the study area. Hence, the contribution of soybean which is an important source of high quality and inexpensive protein and oil, to improvement of nutritional status of children is very important for consideration (Niyibituronsa, Kyallo, Mugo and Gaidashova, 2014).

\section{Objectives of the study}

The general objective of this study was to examine the effect of soybean utilization on child nutrition. Specific objectives include to:

1. determine the personal characteristics of household members;

2. examine preference of soybean as a source of weaning and protein foods;

3. assess soybean utilisation among households;

4. determine nutritional status of children under five years of age; and

5. ascertain constraints to soybean utilisation

\section{Hypotheses of the study}

$\mathrm{H}_{0} 1$ There is no significant difference in soybean utilisation between trained and untrained households.

$\mathrm{H}_{0} 2$ There is no significant relationship between nutritional status of children and soybean utilisation.

$\mathrm{H}_{03}$ There is no significant difference in the nutritional status between children from trained and untrained households.

\section{Study area}

The study was conducted in Chikun Local Government area of Kaduna State. Chikun Local Government Area is one of the five LGAs in BirninGwari zone of the Kaduna Agricultural Development Programme (ADP). It has an area of $4,645 \mathrm{~km}^{2}$ and a population of 368,250 at the 2006 census. Kaduna state is located on the southern end of the high plains of northern Nigeria bounded by parallels 903 ' and 1 32', and extend from the upper river Marya on 6 05'E to 8 48'E. Kaduna State has both the Southern guinea savanna and northern guinea savanna where we have the 


\section{Proceedings of the Annual Conference of the Agricultural Extension Society of}

Nigeria

Number: Twenty-Second Annual Conference

Theme: Mainstreaming Entrepreneurship in Agricultural Extension Practice in Nigeria

Date: $23^{\text {rd }}-26^{\text {th }}$ April, 2017. Venue: University of Port Harcourt, River State, Nigeria

ISSN: 1595 - 1421.http://aesonnigeria.org/ConfProc . Email: editorinchief@aesonnigeria.org

greatest soybean production in Nigeria. The major occupation of the inhabitants of the area is farming and trading. The main food crops grown in the state are yam, cassava, sorghum, millet, soybean, rice, vegetables, groundnut, sweet potatoes, and fruit trees such as mangoes and oranges.

Households constituted the population of this study. These are soybean producing and non-producing households in the study area. Out of the 4 ADP zones in Kaduna State, one zone - BirninGwari with 5 LGAs was randomly selected. Chikun LGA with 30 villages was randomly selected from BirninGwari ADP zone. The villages were classified into soybean producing and non-producing villages based on the findings from the pre-study survey. One village was randomly selected each from the soybean producing and non-producing villages. These were Gonin Gora and Karatudu villages respectively. In Gonin Gora, households that have participated in the soybean production and utilisation training organized by IITA and those that have not participated were identified with the assistance of extension agents from ADP. From the list of those that have participated, a total of 30 households were randomly selected from Gonin Gora. Likewise, 30 households were selected from Karatudu which as the control village. Data were collected using questionnaire and anthropometric measurements. The anthropometric data collection involved only children of the households under survey. Data collected was analysed using frequencies, percentages, Pearson Product Moment Correlation and t-test.

\section{Results and Discussion}

\section{Personal Characteristic of Household Members}

\section{Age of Household Heads}

Table 1 reveals the result on respondents' age in the study area in which majority $(58.4 \%)$ were between $36-40$ years of age while $25 \%$ were between $41-45$ years of age. This indicates that respondents are in their middle and active age. This implies that they will be more receptive to technological innovations as earlier studies have shown an inverse relationship between age and adoption of innovations. The result of this study negates the findings of Amusat and Ademola (2013) who found majority of soybean farmers to be within 41-50years of age.

Table 1: Age distribution of household heads

\begin{tabular}{cc}
\hline Age group & $\begin{array}{c}\text { Percentage } \\
(\mathbf{N}=60)\end{array}$ \\
\hline $25-30$ & 8.3 \\
$31-35$ & 8.3 \\
$36-40$ & 58.4 \\
$41-45$ & 25.0 \\
Total & 100.0 \\
\hline
\end{tabular}


Proceedings of the Annual Conference of the Agricultural Extension Society of Nigeria

Number: Twenty-Second Annual Conference

Theme: Mainstreaming Entrepreneurship in Agricultural Extension Practice in Nigeria

Date: $23^{\text {rd }}-26^{\text {th }}$ April, 2017. Venue: University of Port Harcourt, River State, Nigeria

ISSN: 1595 - 1421.http://aesonnigeria.org/ConfProc . Email: editorinchief@aesonnigeria.org

\section{Number of Years Spent in School by Household Members}

Table 2 shows that only $23.0 \%$ of household members had no formal education while there was varying degree of the number of years of formal education within households. Illiteracy level was higher for spouses (37.2\%) than for other members of the household (household heads - $18.3 \%$, male children - $12.5 \%$ and female children $-19.2 \%$ ). This result implies household heads are more educated than their spouses. Generally, literacy level was higher for male children with $64.6 \%$ having higher number of years (> 7 years) spent in school. This indicates that male children are likely to be more receptive of nutritional innovations as education fosters access to information and enhances utilisation of new ideas.

Table 2: Percentage distribution of household members by years of formal education

\begin{tabular}{cccccc}
\hline $\begin{array}{c}\text { Years in } \\
\text { school }\end{array}$ & $\begin{array}{c}\text { Household } \\
\text { heads(N=60) }\end{array}$ & $\begin{array}{c}\text { Spouses } \\
(\mathbf{N}=\mathbf{7 0})\end{array}$ & $\begin{array}{c}\text { Male } \\
\text { children } \\
\text { (N=48) }\end{array}$ & $\begin{array}{l}\text { Female } \\
\text { children } \\
\text { (N=52) }\end{array}$ & $\begin{array}{c}\text { Total } \\
\text { (N=230) }\end{array}$ \\
\hline None & 18.3 & 37.2 & 12.5 & 19.2 & 23.0 \\
$1-6$ & 36.7 & 25.7 & 22.9 & 32.7 & 29.6 \\
$7-12$ & 41.7 & 30.0 & 41.7 & 30.8 & 35.7 \\
$13-18$ & 3.3 & 7.1 & 22.9 & 17.3 & 11.7 \\
Total & 100 & 100 & 100 & 100 & 100 \\
\hline
\end{tabular}

Number of Years Spent in School by Mothers

Table 3 reveals that there is great variability in the literacy level of women in the study area. While $38 \%$ have no formal education, only $7 \%$ have tertiary education. Generally, literacy level is poor, however, this is more pronounced in untrained households than in trained households where soybean utilisation training takes place. Since women are the major determinants of the food consumed in the homes, this implies that innovation adoption will be more rapid in the trained households than in the untrained households. This is because education increases awareness and reception to new ideas (Okoruwa, 1999).

Table 3: Distribution of mothers in household by years of formal education

\begin{tabular}{lccc}
$\begin{array}{l}\text { Years in } \\
\text { school }\end{array}$ & $\begin{array}{c}\text { Untrained hh } \\
\%(\mathbf{N}=\mathbf{3 2})\end{array}$ & $\begin{array}{c}\text { Trained } \mathbf{~ h h} \\
\%(\mathbf{N}=\mathbf{3 8})\end{array}$ & $\begin{array}{c}\text { Total } \\
\%(\mathbf{N}=\mathbf{7 0})\end{array}$ \\
\hline None & 50.0 & 26.3 & 37.2 \\
$1-6$ & 25.0 & 26.3 & 25.7 \\
$7-12$ & 25.0 & 34.2 & 30.0 \\
$13-18$ & - & 13.2 & 7.1 \\
Total & 100.0 & 100.0 & 100.0 \\
\hline
\end{tabular}

$\mathrm{hh}=$ household 


\section{Proceedings of the Annual Conference of the Agricultural Extension Society of}

Nigeria

Number: Twenty-Second Annual Conference

Theme: Mainstreaming Entrepreneurship in Agricultural Extension Practice in Nigeria

Date: $23^{\text {rd }}-26^{\text {th }}$ April, 2017. Venue: University of Port Harcourt, River State, Nigeria

ISSN: 1595 - 1421.http://aesonnigeria.org/ConfProc . Email: editorinchief@aesonnigeria.org

\section{Sex of Children}

There is relative proportionality in the distribution of male and female children within the households in the study area as shown on Table 4. However, there were more females than males in both producing and non-producing households. This provides a proper and adequate base for the assessment of children's nutritional status.

Table 4: Sex of children in households

\begin{tabular}{lccc}
\hline Sex & $\begin{array}{c}\text { Untrained household } \\
\%(\mathbf{N}=\mathbf{5 2})\end{array}$ & $\begin{array}{c}\text { Trained household } \\
\%(\mathbf{N}=\mathbf{5 0})\end{array}$ & $\begin{array}{c}\text { Total } \\
\%(\mathbf{N}=\mathbf{1 0 2})\end{array}$ \\
\hline Male & 48.1 & 46.0 & 47.1 \\
Female & 51.9 & 54.0 & 52.9 \\
Total & 100 & 100 & 100 \\
\hline
\end{tabular}

\section{Primary Occupation of Household Members}

Table 5 shows that $35.3 \%$ of household members were farmers, $25 \%$ were traders while $22.8 \%$ were civil servants. This implies that household members get income from farming, trading and paid employment. Income determines household welfare, hence, the higher the income derived from a given activity the higher the readiness to adopt technological innovations. This is because there is more promise for improved livelihood from adopting innovations.

\section{Table 5: Primary occupation of household members}

\begin{tabular}{ll}
\hline Primary occupation & Percentage $(\mathbf{N}=\mathbf{1 3 6})$ \\
\hline Crop farming & 26.5 \\
Livestock farming & 8.8 \\
Artisan & 16.9 \\
Trading & 25.0 \\
Civil servant & 22.8 \\
\hline
\end{tabular}

\section{Household Soybean Production Experience}

The result of the analysis on Table 6 shows that household heads had more experience in soybean production than other members of the households. Table 6 also reveals that $31.7 \%$ and $23.3 \%$ of the household heads had $1-5$ and $6-10$ years of farming experience respectively. This was followed by spouses with $18.7 \%$ and $17.1 \%$ production experience of $1-5$ and $6-10$ years respectively. Generally, a few of the household members have more than 10 years' production experience while male and female children have very low soybean production experience as confirmed by their ages. This implies that soybean production and utilisation decisions may remain exclusively that of the household heads and their spouses because of their experience. 
Proceedings of the Annual Conference of the Agricultural Extension Society of Nigeria

Number: Twenty-Second Annual Conference

Theme: Mainstreaming Entrepreneurship in Agricultural Extension Practice in Nigeria

Date: $23^{\text {rd }}-26^{\text {th }}$ April, 2017. Venue: University of Port Harcourt, River State, Nigeria

ISSN: 1595 - 1421.http://aesonnigeria.org/ConfProc . Email: editorinchief@aesonnigeria.org

Table 6: Distribution of household members by year of experience in soybean production

\begin{tabular}{ccccc}
\hline $\begin{array}{c}\text { Production } \\
\text { experience }\end{array}$ & $\begin{array}{c}\text { Household } \\
\text { heads } \\
\%(\mathbf{N}=\mathbf{6 0})\end{array}$ & $\begin{array}{c}\text { Spouses } \\
\%(\mathbf{N}=\mathbf{7 0})\end{array}$ & $\begin{array}{c}\text { Male } \\
\text { children } \\
\%(\mathbf{N}=\mathbf{4 8})\end{array}$ & $\begin{array}{c}\text { Female } \\
\text { children } \\
\%(\mathbf{N}=\mathbf{5 2})\end{array}$ \\
\hline None & 33.3 & 50.0 & 83.3 & 76.9 \\
$1-5$ & 31.7 & 18.7 & 12.5 & 17.3 \\
$6-10$ & 23.3 & 17.1 & 4.2 & 5.8 \\
$11-15$ & - & 5.7 & - & - \\
$16-20$ & 8.3 & 7.1 & - & - \\
$21-25$ & 3.3 & 1.4 & - & - \\
Total & 100 & 100 & 100 & 100 \\
Consumption & & & & \\
experience & & & & \\
None & 46.7 & 52.9 & 54.2 & 50.0 \\
$1-5$ & 5.0 & 5.7 & 10.4 & 13.5 \\
$6-10$ & 23.3 & 20.0 & 23.0 & 23.0 \\
$11-15$ & 10.0 & 12.9 & 10.4 & 7.7 \\
$16-20$ & 11.7 & 7.1 & & 5.8 \\
$21-25$ & 3.3 & 1.4 & - & - \\
Total & 100.0 & 100.0 & 100.0 & 100.0 \\
\hline
\end{tabular}

\section{Household Soybean Consumption Experience}

Table 6 presents the number of years' household members had been consuming soybean in the study area. It was found that majority of the household members (household heads- $46.7 \%$, spouses- $52.9 \%$, male children-54.2\%, female children$50.0 \%)$ had not been consuming soybean. This implies that there is still need for more sensitization of household members on benefits in soybean consumption. The result of this study is not in consonance with Ugwu and Nwoke (2011) who found that soybean products are widely accepted and consumed by over $50 \%$ of adults, $60 \%$ of house wives and over $90 \%$ of growing children.

\section{Preference of Soybean as a Source of Weaning and Protein Foods}

Although mother's milk (breast feeding) contributes more (64\%) as first choice of weaning food, there is little variability among the other sources of weaning food. However, soybean product (soymilk) constitutes $51.4 \%$ of the weaning food as second choice as revealed on Table 7. This indicates that there is growing awareness and preference for soybean product as weaning food. Implicitly, improvement in processing technologies and innovations will be embraced, as soy products are generally being preferred and integrated into the feeding regime of children. The degree of preference for protein foods is shown in Table 7. There is great variability in the choice of protein foods as $37.1 \%$ of the respondents prefer beans to meat $(18.6 \%)$ and fish (14.3\%). Soybean products are less preferred in terms of rating. In spite of the high preference for beans $(37.1 \%)$, meat $(34.3 \%)$ and vegetables $(21.4 \%)$ remain the second preferred source of protein. Table 7 further shows that animal protein foods are less preferred compared to plant protein foods in 


\section{Proceedings of the Annual Conference of the Agricultural Extension Society of Nigeria \\ Number: Twenty-Second Annual Conference \\ Theme: Mainstreaming Entrepreneurship in Agricultural Extension Practice in Nigeria \\ Date: $23^{\text {rd }}-26^{\text {th }}$ April, 2017. Venue: University of Port Harcourt, River State, Nigeria \\ ISSN: 1595 - 1421.http://aesonnigeria.org/ConfProc . Email: editorinchief@aesonnigeria.org}

the study area. This may be due to the adequate knowledge of the nutritive value of the plant products. Also, protein from plant sources is relatively cheaper compare to those from animal sources. Emphasis could be placed on non-animal protein foods and this could be achieved by increasing the awareness of households on the nutritional value of soybean as a good plant protein source.

Table 7: Preference of soybean as a source of weaning and protein foods

\begin{tabular}{llll}
\hline Weaning food & $\begin{array}{l}\mathbf{1}^{\text {st }} \text { choice } \\
\%\end{array}$ & $\begin{array}{c}\mathbf{2}^{\text {nd }} \text { choice } \\
\%\end{array}$ & $\begin{array}{l}\mathbf{3}^{\text {rd }} \text { choice } \\
\%\end{array}$ \\
\hline Mother's milk & 65.7 & 11.4 & 22.9 \\
Maize & 10.0 & 28.6 & - \\
Maize (Akamu) & 18.6 & 11.4 & 77.1 \\
Rice & 1.4 & - & - \\
Soymilk & 7.1 & 51.4 & - \\
Protein food & & & \\
Meat & 18.6 & 34.3 & 22.9 \\
Fish & 14.3 & 17.1 & - \\
Beans & 37.1 & 11.4 & 14.3 \\
Egg & 4.3 & 11.4 & 7.1 \\
Vegetable & 8.6 & 21.4 & 30.0 \\
Soya milk & 11.4 & 2.8 & 7.1 \\
Milk & 7.1 & - & 14.3 \\
Groundnut & 7.1 & - & 14.3 \\
\hline
\end{tabular}

\section{Utilisation of Soybean}

Table 8 shows that almost all respondents in untrained households never use soybean products. Only one soybean product (dadawa) is currently being used by $83 \%$ of respondents from untrained households. According to Amusat and Ademola (2013), at the household level, soybean serves as a good substitute for locust bean in preparation of dadawa (local condiment in soup preparation), when ground it is used in place of melon in soup and is a good source of cheap protein. Very few respondents have once experimented soy moin-moin while $4 \%$ and $7 \%$ have used and abandoned soy milk and soy soup respectively. However, a majority of respondents from trained households are currently using most soybean products. This scenario is informed by the training received on soybean utilisation among households in the study area. This implies that training is the bedrock of increased utilisation of soybean products among households in rural areas. This is in tandem with the assertion of Dugje et al. (2009) that it is believed that soybean production will increase as more farmers become aware of the potentials of the crop not only for cash/food but also for soil fertility improvement and Striga control. However, few respondents had used and abandoned some soybean products, while $37 \%$ and $35 \%$ of respondents had once experimented soy akara and soy gari respectively. 


\section{Proceedings of the Annual Conference of the Agricultural Extension Society of Nigeria \\ Number: Twenty-Second Annual Conference \\ Theme: Mainstreaming Entrepreneurship in Agricultural Extension Practice in Nigeria \\ Date: $23^{\text {rd }}-26^{\text {th }}$ April, 2017. Venue: University of Port Harcourt, River State, Nigeria \\ ISSN: 1595 - 1421.http://aesonnigeria.org/ConfProc . Email: editorinchief@aesonnigeria.org}

Table 8: Percentage utilisation of soybean by respondents

\begin{tabular}{|c|c|c|c|c|c|c|c|c|}
\hline \multirow[t]{2}{*}{$\begin{array}{l}\text { Soybean } \\
\text { products }\end{array}$} & \multicolumn{2}{|c|}{$\begin{array}{l}\text { Currently } \\
\text { using }\end{array}$} & \multicolumn{2}{|c|}{$\begin{array}{l}\text { Use and } \\
\text { abandoned }\end{array}$} & \multicolumn{2}{|c|}{$\begin{array}{l}\text { Experimented } \\
\text { once }\end{array}$} & \multicolumn{2}{|c|}{ Never use } \\
\hline & $\begin{array}{l}\mathrm{UH} \\
\%\end{array}$ & $\begin{array}{l}\mathrm{TH} \\
\%\end{array}$ & $\begin{array}{l}\text { UH } \\
\%\end{array}$ & $\begin{array}{l}\mathrm{TH} \\
\%\end{array}$ & $\begin{array}{l}\mathrm{UH} \\
\%\end{array}$ & $\begin{array}{l}\mathrm{TH} \\
\%\end{array}$ & $\begin{array}{l}\mathrm{UH} \\
\%\end{array}$ & $\begin{array}{l}\mathrm{TH} \\
\%\end{array}$ \\
\hline Dadawa & 83 & 100 & - & - & 3 & - & 13 & - \\
\hline Soy moinmoin & - & 64 & - & 14 & - & 18 & 100 & 5 \\
\hline Soymilk & - & 97 & 4 & - & - & - & 96 & 3 \\
\hline Soy ogi & - & 83 & - & 13 & - & - & 100 & 4 \\
\hline Soy akara & - & 26 & - & 11 & - & 37 & 100 & 26 \\
\hline Soy soup & - & 69 & 7 & 7 & - & 3 & 93 & 21 \\
\hline Soy vegetable & - & 85 & & 4 & - & - & 100 & 11 \\
\hline soup & & & & & & & & \\
\hline Soy gari & - & 5 & - & 5 & - & 35 & 100 & 55 \\
\hline Soy eba & - & - & - & 17 & - & 8 & 100 & 75 \\
\hline Soy flour & - & 67 & - & 5 & - & - & 100 & 29 \\
\hline Soy snacks & - & 25 & - & 17 & - & 8 & 100 & 50 \\
\hline Others & - & 76 & - & 10 & - & 4 & 100 & 10 \\
\hline
\end{tabular}

$\mathrm{UH}-$ Untrained households $\quad \mathrm{TH}-$ Trained households

\section{Nutritional Status of Children under Five Years of Age}

Assessment of nutritional status of children was based on the anthropometric measurements of the children's height, weight, age and mid-arm circumference. The nutritional status differs among children of different ages and under different household conditions (whether producing or not/trained in soybean utilisation or not). These are presented under soybean malnutrition conditions.

\section{Loss of Weight among Children under Five Years of Age}

Table 9 shows that majority of the children below the age of five in the study area were normal $(62.3 \%)$. Children below the age of five suffer from mild $(14.8 \%)$, moderate $(9.8 \%)$ and severe $(13.1 \%)$ malnutrition. There were variations in degree of malnutrition between soybean trained and untrained households in the study area. While $66.7 \%$ of the children from soybean trained households were normal, $57.1 \%$ of children from untrained households were normal.

Children from soybean trained households suffer less malnutrition than those from untrained households. While 12.1, 9.1 and 12.1 percent of children are mildly, moderately and severely malnourished respectively in soybean trained households, 17.9, 10.7 and 13.1 percent suffer similar malnutrition in untrained soybean households. This shows that soybean utilisation is important and has improved the health status of producing households owing to its consumption. This result follows the high degree of soybean utilisation among producing households, a situation occasioned by the training on soybean utilisation. 


\section{Proceedings of the Annual Conference of the Agricultural Extension Society of Nigeria \\ Number: Twenty-Second Annual Conference \\ Theme: Mainstreaming Entrepreneurship in Agricultural Extension Practice in Nigeria \\ Date: $23^{\text {rd }}-26^{\text {th }}$ April, 2017. Venue: University of Port Harcourt, River State, Nigeria \\ ISSN: 1595 - 1421.http://aesonnigeria.org/ConfProc . Email: editorinchief@aesonnigeria.org}

Table 9: Nutritional status of children under five years of age

\begin{tabular}{|c|c|c|c|c|}
\hline $\begin{array}{l}\text { Loss in } \\
\text { weight }\end{array}$ & $\begin{array}{c}\text { Normal (95- } \\
100 \% \text { of } \\
\text { standard) }\end{array}$ & $\begin{array}{l}\text { Mild }(90-95 \% \\
\text { of standard) }\end{array}$ & $\begin{array}{l}\text { Moderate PEM } \\
\text { (85-90\% of } \\
\text { standard) }\end{array}$ & $\begin{array}{c}\text { Severe PEM }(< \\
85 \% \text { of } \\
\text { standard })\end{array}$ \\
\hline & $\%(\mathrm{~N}=38)$ & $\%(\mathrm{~N}=9)$ & $\%(\mathrm{~N}=6)$ & $\%(\mathrm{~N}=8)$ \\
\hline Trained & 66.7 & 12.1 & 9.1 & 12.1 \\
\hline Untrained & 57.1 & 17.9 & 10.7 & 13.1 \\
\hline Total & 62.3 & 14.8 & 9.8 & 13.1 \\
\hline $\begin{array}{l}\text { Growth } \\
\text { retardation }\end{array}$ & $\%(N=9)$ & $\%(\mathrm{~N}=15)$ & $\%(\mathrm{~N}=27)$ & $\%(\mathrm{~N}=10)$ \\
\hline Trained & 18.1 & 21.2 & 48.5 & 12.1 \\
\hline Untrained & 10.7 & 28.6 & 39.3 & 21.4 \\
\hline Total & 14.8 & 24.6 & 44.2 & 16.4 \\
\hline
\end{tabular}

\section{Growth Retardation among Children}

Table 9 shows that the children under five years of age in the study area suffer from growth retardation. Generally, only $14.8 \%$ of the children had normal growth in height, $44.2 \%$ were moderately malnourished while $24.6 \%$ and $16.4 \%$ of the children were mildly and severely malnourished respectively. This scenario is different between soybean producing and non-producing households. Children from soybean producing (trained) households are better off in terms of growth than those of non-producing (untrained) soybean households. While children from trained households were normal (18.1\%), mildly $(21.2 \%)$ and severely $(12.1 \%)$ malnourished, $10.7 \%, 28.6 \%$, and $21.4 \%$ of the children from untrained households suffer the same degree of malnutrition. This result further indicates the relevance of soybean in the diet of children in the study area. Awareness of soybean as a protein rich crop and its utilisation among the trained and producing households accounts for these differences.

\section{Constraints to Soybean Utilisation}

Table 10 reveals that lack of processing equipment (32.2\%) and time factor $(26.2 \%)$ were the major factors constraining the utilisation of soybean. Other constraints as shown in Table 10 include beanie taste of soybean (16.4\%), difficulty in soybean preparation (15.6\%) and the lack of technical knowledge on soybean utilisation $(9.6 \%)$. This implies that with the availability of soybean processing equipment and intensification of awareness campaign, proper training on soybean processing will enhance soybean utilisation in the study area.

Table 10: Constraints to soybean utilisation

\begin{tabular}{ll}
\hline Constraints & Percentage \\
\hline Lack of processing equipment & 32.2 \\
Lack of technical knowledge & 9.6 \\
Difficulty in soybean preparation & 15.6 \\
The beanie taste of soybean & 16.4 \\
Time factor & 26.2 \\
\hline
\end{tabular}




\section{Proceedings of the Annual Conference of the Agricultural Extension Society of}

Nigeria

Number: Twenty-Second Annual Conference

Theme: Mainstreaming Entrepreneurship in Agricultural Extension Practice in Nigeria

Date: $23^{\text {rd }}-26^{\text {th }}$ April, 2017. Venue: University of Port Harcourt, River State, Nigeria

ISSN: 1595 - 1421.http://aesonnigeria.org/ConfProc . Email: editorinchief@aesonnigeria.org

\section{Difference in Soybean Utilisation among Trained and Untrained Households}

Table 11 shows the t-test analysis of the difference in soybean utilisation among trained and untrained households shows significant difference at the $1 \%$ level of probability. Therefore, the null hypothesis of no significant difference is rejected and the alternative hypothesis accepted that differences exist in the level of utilisation of soybean among trained and untrained households. There is marked differences in the level of utilisation of soybean between trained and untrained households. This accounts for significant difference in the t-test result. This result indicates that training is important in enhancing the utilisation of soybean.

Table 11: Difference in soybean utilisation between trained and untrained households

\begin{tabular}{lll}
\hline Categories & Mean & t-value \\
\hline Trained & 68.3 & $12.4^{\star}$ \\
Untrained & 22.9 &
\end{tabular}

${ }^{*} \mathrm{P} \leq 0,05$

Table 12 shows that a positive significant relationship exists between utilisation and children nutritional status in the study area. The correlation coefficient was significant at $1 \%$ level of significant. Hence, the null hypothesis is rejected and the alternative hypothesis accepted. This result implies soybean utilisation plays a significant role in the diet of children under five years of age. Also, it implies that the nutritional status of the children improves with increase in soybean utilisation. The more they utilized soybean, the better the nutritional status of their children. Therefore, households that utilized more soybeans have their children with improved nutritional status. The weak preference of the household for meat as a source of protein further suggests greater emphasis on soybean utilisation as second best alternative to meeting the protein nutritional need of children (Okoruwa, 1999).

Table 12: Correlation analysis between soybean utilisation and nutritional status of children

\begin{tabular}{llll}
\hline Categories & r-value & p-value & Remark \\
\hline $\begin{array}{l}\text { Nutritional status and } \\
\text { soybean utilisation }\end{array}$ & 0.34 & $0.002^{*}$ & Significant \\
\hline
\end{tabular}

${ }^{*} \mathrm{P} \leq 0,05$

Table 13 shows that there is a significant difference in the nutritional status of children from soybean trained and untrained households. This result shows that soybean production significantly influences the nutritional status of children from trained household compare to untrained household. This implies that soybean production should be encouraged in the study area. 
Proceedings of the Annual Conference of the Agricultural Extension Society of Nigeria

Number: Twenty-Second Annual Conference

Theme: Mainstreaming Entrepreneurship in Agricultural Extension Practice in Nigeria

Date: $23^{\text {rd }}-26^{\text {th }}$ April, 2017. Venue: University of Port Harcourt, River State, Nigeria

ISSN: 1595 - 1421.http://aesonnigeria.org/ConfProc . Email: editorinchief@aesonnigeria.org

Table 13: Difference in nutritional status between children from trained and untrained households

\begin{tabular}{lll}
\hline Categories & Mean & $\mathrm{t}$-value \\
\hline Trained & 25.0 & 2.32 \\
Untrained & 11.7 & \\
\hline
\end{tabular}

${ }^{*} \mathrm{P} \leq 0,05$

\section{Conclusion and Recommendations}

Training played an important role in soybean utilisation. Children from trained households had higher nutritional status than those from untrained households implying soybean utilisation influences child nutrition. However, soybean utilisation is constrained mainly by lack of processing equipment time factor and beanie taste of soy products. The study recommends that there should be intensive enlightenment of rural households on the nutritive value and utilisation of soybean. More research should be focused on processing technologies that saves time and reduce the beanie taste of soy products by incorporating local seasoning materials into the product to enhance acceptability.

\section{References}

Amusat, A.S. and A.O. Ademola (2013).Utilisation of Soybean in Oniyo Community of Oyo State, Nigeria.Global Journal of Science Frontier Research Agriculture and Veterinary. Volume 13 Issue 7 Version 1.0

Bantamen G, Belaynew W and Dube J(2014). Assessment of Factors Associated with Malnutrition among Under Five Years Age Children at MachakelWoreda, Northwest Ethiopia: A Case Control Study

Dugje, I.Y., Omoigui, L.O., Ekeleme, F., Bandyopadhyay, R., Kumar, P.L. and A.Y. Kamara. (2009). Farmers' Guide to Soybean Production in Northern Nigeria. IITA: Ibadan.

Erdman JW Jr (2000) AHA Science Advisory: Soy protein and cardiovascular disease: A statement for healthcare professionals from the Nutrition Committee of the AHA. Circulation 102: 2555-2559.

Fabiyi, E.F. 2006. Soyabean Processing, Utilization and Health Benefits. Pakistan Journal of Nutrition 5 (5): 453-457.

Horizon International (2011).An effort to promote the production and consumption of soybeans as a means of improving nutrition in Nigeria. Retrieved March 3rd, 2017 from www.solutions-site.org/taxonomy/term/65

Janevic T, Petrovic O, Bjelic I, Kubera A (2010) Risk factors for child hood malnutrition in Roma settlements in Serbia. BMC public health 10: 509.

John G. Safari, Zacharia S. Masanyiwa and James E. Lwelamira (2015). Prevalence and Factors Associated with Child Malnutrition in Nzega District, Rural Tanzania. 
Proceedings of the Annual Conference of the Agricultural Extension Society of Nigeria

Number: Twenty-Second Annual Conference

Theme: Mainstreaming Entrepreneurship in Agricultural Extension Practice in Nigeria

Date: $23^{\text {rd }}-26^{\text {th }}$ April, 2017. Venue: University of Port Harcourt, River State, Nigeria

ISSN: 1595 - 1421.http://aesonnigeria.org/ConfProc . Email: editorinchief@aesonnigeria.org

Korde LA, Wu AH, Fears T, Nomura AM, West DW, et al. (2009) Childhood soy intake and breast cancer risk in Asian American women. See comment in PubMed Commons below Cancer Epidemiol Biomarkers Prev 18: 1050-1059.

Niyibituronsa M. 1., Kyallo F., Mugo C and S Gaidashova (2014). Improving the Nutritional Status of Malnourished Children using Soybean Products in Rwanda. African Journal of food Agriculture, Nutrition and Development. Volume 14 No. 4, 9136-9153

Olatunji S. O, Etuk U. R. and Adesope O. M. (2012). Factors Related to Continuity in Utilisation of Soya Bean Products by Farm-Families in Abia State, Nigeria. J AgriSci, $3(1): 15-20$

Okoruwa A. E. (1999).Soybean Processing and Utilisation for Healthy Nutrition in West Africa. Final Report of IDRC/IITA Soybean Utilisation Project, Phase III, (1004-1999) IITA, Ibadan, Nigeria, 51p.

Osera T, Tsutie S, Kobayashi M, Kurihara N(2012) Relationship of mothers' food preferences and attitudes with children's preferences. Food and NutrSci 3: 1461-1466.

Osera T, Tsutie S, Kobayashi M, Segawa Y, Kurihara N, et al. (2016) The effect of mothers'and fathers' food preferences on children's preferences with their attitude. Food and NutrSci 6: 93-100.

Prüss-Üstün, A., Bos, R., Gore, F., Bartram, J. (2008). Safer water, better health - Costs, benefits and sustainability of interventions to protect and promote health.World Health Organization (WHO), Geneva, Switzerland.

Ugwu D. S. and Nwoke U. M. (2011).Assessment of soybean products acceptability and consumption in Orumba South Local Government Area of Anambra State Nigeria.International Research Journal of Agricultural Science and Soil Science (ISSN: 2251-0044) Vol. 1(8) pp. 314-325. Available online http://www.interesjournals.org/IRJAS

Walker, [edited by] Christopher Duggan, John B. Watkins, W. Allan (2008). Nutrition in pediatrics: basic science, clinical application. Hamilton: BC Decker. pp. 127-141.

Wikipedia, the free encyclopedia (2017). Malnutrition in children. Retrieved April 5th, 2017 from http://en.wikipedia.org/wiki/Manultrition_in_children

World's Healthiest Foods (2004). Feeling great 2004 file://F:NewFolderltheWorld'shtm, pp: $1-16$.

World's Healthiest Foods (2011). Food Soybean protein, www.whf

You, D., Jones G. and T.Wardlaw (2012). Levels and trends in child mortality report. United Nations Inter-Agency Group for Child Mortality Estimation.

You, D., Jones G. and T.Wardlaw, (2012). Levels and trends in child mortality report. United Nations Inter-Agency Group for Child Mortality Estimation. 